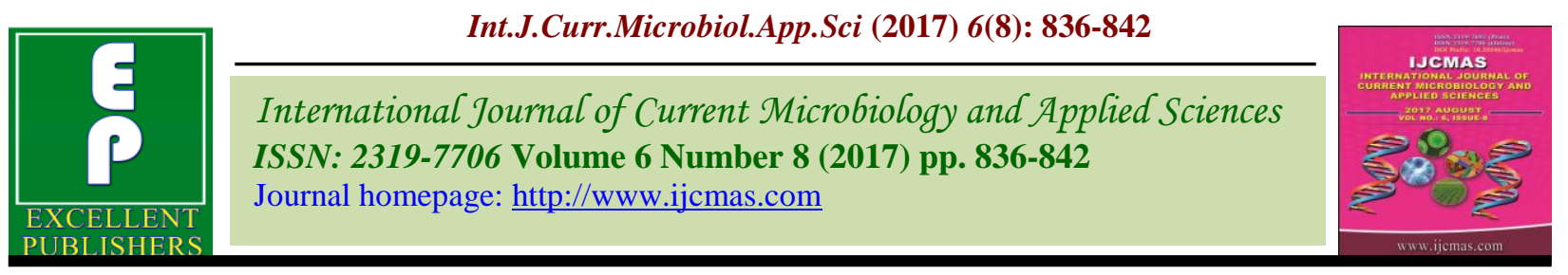

Original Research Article

https://doi.org/10.20546/ijcmas.2017.608.106

\title{
Surface Sterilization for Reducing Microbial Contamination in In Vitro Propagation of Lasora (Cordia myxa Roxb.) Using Nodal Segments
}

\author{
Minakshi Padhi* and S.P. Singh \\ Department of Horticulture, Institute of Agricultural Sciences, \\ Banaras Hindu University, Varanasi, India \\ *Corresponding author
}

\section{A B S T R A C T}

Keywords

Aseptic,

Sterilization,

Explants,

Mercuric chloride,

Sodium

hypochloride.

Article Info

Accepted:

14 June 2017

Available Online:

10 August 2017
Lasora (Cordia myxa Roxb.) is commonly grown as minor or underexploited crop having great medicinal and food value which belongs to the family Boraginaceae, originates along the Himalayan tract upto 1,500 metres. In-vitro technique is accepted widely to produce virus free plants in a very large number. Production of virus free planting material using meristem culture has been made possible in this crop. An experiment entitled "Surface sterilization for reducing microbial contamination in In-vitro propagation of lasora (Cordia myxa Roxb.) using nodal segments" was conducted at Institute of Agricultural Sciences, Banaras Hindu University, Varanasi during 2015-16 which aims to elucidate standardization of sterilization process through various concentration of $\mathrm{HgCl}_{2}$ at $0.1 \%$ and $\mathrm{NaOCl}$ at $1 \%$ concentration followed by $70 \%$ ethanol in lasora. The effect of various exposure time of $\mathrm{HgCl}_{2}$ and $\mathrm{NaOCl}$ on different explants was studied and found to be best when explants treated with $\mathrm{HgCl}_{2}(0.1 \%)$ for 10 minutes, resulted 85.50 per cent aseptic culture and 83.25 per cent survival of explants. Whereas, maximum aseptic culture was found with $1 \%$ sodium hypochloride when treated for 21 minutes followed by $70 \%$ ethanol for $30 \mathrm{sec}$ This can be explained by the fact that requirements for surface sterilization are different and depend on the tissue type and the nature of the explants used for in-vitro propagation.

\section{Introduction}

Cordia myxa is commonly known as Lasora belongs to the family Boraginaceae which originates along the Himalayan tract upto 1,500 metres, with its natural habitat extending through the forests of India, Nepal and Myanmar. It is a large evergreen tree and growing 8 to 12 meters in height. The shoot of lasora is erect, cylindrical with brownish and fissured bark. The leaves are broad, ovate, alternate, glabrous above and pubescent beneath. Fruits are full of viscous sticky mucilage become slightly sweet in taste. From the economic point of view, it is very important woody plant. Its fresh foliage and tender twigs are very useful for fodder of cattles. The extract of leaves is used to cure cough and urinary disorder. The unripe fruits of Cordia myxa are pickled and cooked as vegetable while ripe fruits with mucilaginous pulp are eaten (Aberoumand and Deokule, 2010). As it is considered as an underutilization fruit crop due to habitat destruction and predation, exploitation of this crop is very necessary. In-vitro technique is accepted widely to produce virus free plants in a very large number. Production of virus 
free planting material using meristem culture has been made possible in this crop. It is the technique of growing plant cells, tissues and organs in an artificial prepared nutrient medium under aseptic conditions (Bajaj, 1986). Sterilization is a very important aspect of tissue culture, as tissue culture aims at in vitro propagation of a desired plant material, which should be free from contamination of any other microorganism. The culture media which is prepared for the growth of explants is also conducive for the growth of other microorganisms like bacteria and fungi. Therefore, appropriate measures should be taken to avoid contamination by these microorganisms. The present research effort aims to elucidate standardization of sterilization process with $0.1 \%$ of $\mathrm{HgCl}_{2}$ and $1 \%$ of $\mathrm{NaOCl}$ at different time exposure in lasora.

\section{Materials and Methods}

The present investigation was carried out in Tissue culture laboratory, Department of Horticulture, Institute of Agricultural Sciences, Banaras Hindu University, Varanasi during the year 2015-2016. Varanasi city is located $25^{\circ} 10^{\prime}$ North latitude, $83^{\circ} 03^{\prime}$ 'East longitudes and at an altitude of $123.23 \mathrm{~m}$ above the mean sea level. The climate of Varanasi is sub-tropical with dry hot summers and cool winter with average rainfall of about $1,000 \mathrm{~mm}$ per annum. The in-vitro propagation was carried out by selecting healthy nodal segments or internodal segments of size 1.5-2.5 cm (length) and 0.2 $\mathrm{cm}$ (width) from the mother plant, called explants, with early maturing, free from insect, pests and diseases and vigorous, using sterilized knife or blade. Spraying with SAAF $(0.2 \%)$ was done 2-3 days before collection of explants. Test tubes, flasks, etc. plugged with non-absorbent cotton and Petri plates, pipettes, glassware, etc. wrapped with brown paper and aluminium foils were sterilized in autoclave at $1.2 \mathrm{~kg} / \mathrm{cm}^{2}$ pressure approximately at $121^{\circ} \mathrm{C}$ for 40 minutes. All the cultured vessels used during experimentation were dried in hot air oven at $120-130^{\circ} \mathrm{C}$ for $8-10$ hours. The UV-light of laminar air-flow chamber was switched on 30-40 minutes before use and the working place was surface sterilized by thorough cleaning with methylated spirit. UV- light was turned off with switching on the air-flow during the operation. All the forceps, scalpels, scissors etc. were dipped in spirit inside the laminar air-flow chamber and were frequently flame sterilized and cooled down before starting the inoculation process. The explants were subjected to $1 \%$ sodium hypochloride and mercuric chloride at $0.1 \%$ concentration at various intervals of time as shown in tables 2 and 3 followed by a 5 minutes rinse in sterile distilled water under aseptic conditions in the laminar air flow chamber. All the explants were exposed above the surface of the medium. The composition of MS (Murashige and Skoog, 1962) medium was given in table 1. Appropriate quantities of various stock solutions (I,II,III,IV) and plant growth regulators were pipette out and stirred with $400 \mathrm{ml}$ distilled water on a magnetic stirrer. After adding sucrose at $3 \%$ concentration, $\mathrm{pH}$ was adjusted to 5.8 with $0.1 \mathrm{~N} \mathrm{NaOH}$ and $0.1 \mathrm{HCl}$. Lastly agar agar at $0.7 \%$ concentration was added and final volume was made to $1 \mathrm{~L}$ with adding distilled water.

There were ten treatments replicated four times and statistically analysed by completely randomized design by using the SAS software version 9.1 (SAS Institute, Cary, NC). Plants grown in the field are typically dirtier than those grown in a greenhouse or growth chamber. Surface sterilization is an imperative step prior to in-vitro culture of any plant tissue. The effect of exposure time of various surface sterilants on per cent aseptic culture and per cent survival of explants were recorded. 


\section{Results and Discussion}

For the establishment of in-vitro culture, surface sterilization of explants was essential as the culture medium is the most suitable for the growth of microbes. There were two sets of experiments which were carried out using three different sterilants to find out the effect of surface sterilization for reducing microbial contamination in in-vitro technique.

Mercuric chloride, sodium hypochloride and ethanol were used as sterilizing agents at $0.1 \%, 1 \%$ and $70 \%$ concentration respectively at different interval of exposure of time to determine the most effective sterilant using MS medium effectiveness in sterilization procedure, ethanol was normally applied earlier to treatment or with other compounds.

There was significant difference among treatments sterilized by sodium hypochloride (Table 2). Maximum survival percentage was obtained when explants treated with $1 \%$ sodium hypochloride for 15 minutes followed by $70 \%$ ethanol for $30 \mathrm{sec}$.

Maximum aseptic culture was found with $1 \%$ sodium hypochloride when treated for 21 minutes followed by $70 \%$ ethanol for $30 \mathrm{sec}$ which was at par with $1 \%$ sodium chloride + $70 \%$ ethanol for 18 minutes, $1 \%$ sodium hypochloride $+70 \%$ ethanol for 24 minutes + $30 \mathrm{sec}$ and $1 \%$ sodium hypochloride $+70 \%$ ethanol for 27 minutes $+30 \mathrm{sec}$.

A keen observation was recorded for maximum contamination due to microbes when explants treated with $1 \%$ sodium hypochloride for $6 \mathrm{~min}$ followed by washing with $70 \%$ ethanol for 30 sec. Maximum survival percentage of explants was exhibited with sodium hypochloride $1 \%+70 \%$ ethanol sterilized for 15 minutes $+30 \mathrm{sec}$ followed by $1 \%$ sodium hypochloride $+70 \%$ ethanol for 12 minutes $+30 \mathrm{sec}, 1 \%$ sodium hypochloride $+70 \%$ ethanol for 18 minutes $+30 \mathrm{sec}$ and
$1 \%$ sodium hypochloride $+70 \%$ ethanol for $21 \mathrm{~min}+30 \mathrm{sec}$. It is interested to note that treatment $1 \%$ sodium hypochloride $+70 \%$ ethanol for 15 minutes $+30 \mathrm{sec}$ gave pronounced effect on survival which was statistically higher than any other treatments. Control and Sodium hypochloride at $1 \%+70$ $\%$ ethanol for $30 \mathrm{sec}$ failed to exert any effect and resulted into $0.00 \%$ survival.

In another experiment, mercuric chloride was alone used for sterilization of explants (Table 3). Mercuric chloride at $0.1 \%$ for 29 minutes sterilization resulted in maximum aseptic percentage (88.25) which was statistically at par with mercuric chloride $0.1 \%$ for 18 minutes, $0.1 \%$ mercuric chloride for 10 minutes and $0.1 \%$ mercuric chloride for 16 minutes sterilization.

Contamination was noticed with control and $0.1 \%$ mercuric chloride for 4 min sterilization which resulted in $0.00 \%$ aseptic cultured. Mercuric chloride at $0.1 \%$ for 10 minutes sterilization exhibited maximum survival of explants (83.25) which was significantly higher than other treatments.

In general, a decreasing tend in survival percentage was noticed with control and $0.1 \%$ mercuric chloride for 4 minutes sterilization.

Sodium hypocholride has turned out better sterilants than other hypochlorides due to bleaching effect of the later. Available chlorine was sterilized the explants effectively to reduce the chance of contamination. Hence used in sterilization for potato tubers (Badoni and Chauhan, 2010). Whereas, mercuric chloride gave maximum survival of explants with minimum tissue injury when treated for 4 minutes in strawberry (Rattanpal et al., 2011). Sodium hypochloride is highly effective against all kinds of bacteria, fungi and viruses. 
Table.1 Composition of Murashige and Skoog (MS) medium

\begin{tabular}{|c|c|c|}
\hline Components & Concentration $(\mathrm{mg} / \mathrm{L})$ & $\begin{array}{l}\text { Amount in stock } \\
\text { solution(mg/L) }\end{array}$ \\
\hline Macronutrients & & $(20 x)$ \\
\hline $\mathrm{NH}_{4} \mathrm{NO}_{3}$ & 1650 & 33000 \\
\hline $\mathrm{KNO}_{3}$ & 1900 & 38000 \\
\hline $\mathrm{CaCl}_{2} .2 \mathrm{H}_{2} \mathrm{O}$ & 440 & 8800 \\
\hline $\mathrm{MgSO}_{4} .7 \mathrm{H}_{2} \mathrm{O}$ & 370 & 7400 \\
\hline $\mathrm{KH}_{2} \mathrm{PO}_{4}$ & 170 & 3400 \\
\hline II. Micronutrients & & $(200 x)$ \\
\hline KI & 0.83 & 166 \\
\hline $\mathrm{H}_{3} \mathrm{BO}_{3}$ & 6.2 & 1240 \\
\hline $\mathrm{MnSO}_{4} 4 \mathrm{H}_{2} \mathrm{O}$ & 22.3 & 4460 \\
\hline $\mathrm{ZnSO}_{4} .7 \mathrm{H}_{2} \mathrm{O}$ & 8.6 & 1720 \\
\hline $\mathrm{Na}_{2} \mathrm{MoO}_{4} 2 \mathrm{H}_{2} \mathrm{O}$ & 0.25 & 50 \\
\hline $\mathrm{CuSO}_{4} .5 \mathrm{H}_{2} \mathrm{O}$ & 0.025 & 5 \\
\hline $\mathrm{CoCl}_{2} \cdot 6 \mathrm{H}_{2} \mathrm{O}$ & 0.025 & 5 \\
\hline III. Fe-EDTA & & $(200 \mathrm{X})$ \\
\hline $\mathrm{FeSO}_{4} .7 \mathrm{H}_{2} \mathrm{O}$ & 27.8 & 5560 \\
\hline $\mathrm{Na}_{2}$ EDTA. $2 \mathrm{H}_{2} \mathrm{O}$ & 37.3 & 7460 \\
\hline IV. Vitamins and Amino acids & & $(200 x)$ \\
\hline Myoinositol & 100 & 20000 \\
\hline Nicotinic acid & 0.5 & 100 \\
\hline Pyridoxine $\mathrm{HCl}$ & 0.5 & 100 \\
\hline Thiamine $\mathrm{HCl}$ & 0.5 & 20 \\
\hline Glycine & 2.0 & 400 \\
\hline
\end{tabular}


Table.2 Effect of exposure time of sodium hypochloride on the asepsis of nodal segment cultures

\begin{tabular}{|c|c|c|c|}
\hline Treatment & Time & $\begin{array}{c}\text { Aseptic cultures } \\
(\%)\end{array}$ & Survival (\%) \\
\hline $\begin{array}{c}\mathrm{NaOCl}_{2}(1.0 \%)+ \\
70 \% \text { Ethanol }\end{array}$ & $0 \mathrm{~min}+30 \mathrm{sec}$ & 0.00 & 0.00 \\
\hline $\begin{array}{c}\mathrm{NaOCl}_{2}(1.0 \%)+ \\
70 \% \text { Ethanol }\end{array}$ & $3 \mathrm{~min}+30 \mathrm{sec}$ & 0.00 & 0.00 \\
\hline $\begin{array}{c}\mathrm{NaOCl}_{2}(1.0 \%)+ \\
70 \% \text { Ethanol }\end{array}$ & $6 \mathrm{~min}+30 \mathrm{sec}$ & 16.82 & 23.68 \\
\hline $\begin{array}{c}\mathrm{NaOCl}_{2}(1.0 \%)+ \\
70 \% \text { Ethanol }\end{array}$ & $9 \mathrm{~min}+30 \mathrm{sec}$ & 32.96 & 34.17 \\
\hline $\begin{array}{c}\mathrm{NaOCl}_{2}(1.0 \%)+ \\
70 \% \text { Ethanol }\end{array}$ & $12 \mathrm{~min}+30 \mathrm{sec}$ & 53.65 & 53.63 \\
\hline $\begin{array}{c}\mathrm{NaOCl}_{2}(1.0 \%)+ \\
70 \% \text { Ethanol }\end{array}$ & $15 \mathrm{~min}+30 \mathrm{sec}$ & 78.99 & 61.96 \\
\hline $\begin{array}{c}\mathrm{NaOCl}_{2}(1.0 \%)+ \\
70 \% \text { Ethanol }\end{array}$ & $18 \mathrm{~min}+30 \mathrm{sec}$ & 81.03 & 50.92 \\
\hline $\begin{array}{c}\mathrm{NaOCl}_{2}(1.0 \%)+ \\
70 \% \text { Ethanol }\end{array}$ & $21 \mathrm{~min}+30 \mathrm{sec}$ & 85.24 & 37.55 \\
\hline $\begin{array}{c}\mathrm{NaOCl}_{2}(1.0 \%)+ \\
70 \% \text { Ethanol }\end{array}$ & $24 \mathrm{~min}+30 \mathrm{sec}$ & 82.12 & 30.81 \\
\hline $\begin{array}{c}\mathrm{NaOCl}_{2}(1.0 \%)+ \\
70 \% \text { Ethanol }\end{array}$ & $27 \mathrm{~min}+30 \mathrm{sec}$ & 83.28 & 21.33 \\
\hline S.E. $(\mathrm{m})$ & & 2.43 & 3.16 \\
\hline C.D. at $5 \%$ & & 7.05 & 4.48 \\
\hline
\end{tabular}

Table.3 Effect of exposure time of mercuric chloride on the asepsis of nodal segment cultures

\begin{tabular}{|c|c|c|c|}
\hline Treatment & Time (minutes) & $\begin{array}{c}\text { Aseptic cultures } \\
(\%)\end{array}$ & Survival (\%) \\
\hline $\mathrm{HgCl}_{2}(0.1 \%)$ & 0.00 & 0.00 & 0.00 \\
\hline $\mathrm{HgCl}_{2}(0.1 \%)$ & 4.00 & 0.00 & 0.00 \\
\hline $\mathrm{HgCl}_{2}(0.1 \%)$ & 6.00 & 21.25 & 31.75 \\
\hline $\mathrm{HgCl}_{2}(0.1 \%)$ & 8.00 & 62.25 & 61.75 \\
\hline $\mathrm{HgCl}_{2}(0.1 \%)$ & 10.00 & 85.50 & 83.25 \\
\hline $\mathrm{HgCl}_{2}(0.1 \%)$ & 12.00 & 51.25 & 63.25 \\
\hline $\mathrm{HgCl}_{2}(0.1 \%)$ & 14.00 & 82.00 & 49.50 \\
\hline $\mathrm{HgCl}_{2}(0.1 \%)$ & 16.00 & 85.25 & 34.75 \\
\hline $\mathrm{HgCl}_{2}(0.1 \%)$ & 18.00 & 86.75 & 24.00 \\
\hline $\mathrm{HgCl}_{2}(0.1 \%)$ & 20.00 & 88.25 & 18.00 \\
\hline $\mathrm{S.E.}(\mathrm{m})$ & & 2.52 & 1.54 \\
\hline $\mathrm{C.D.}$ at $5 \%$ & & 7.33 & 4.48 \\
\hline
\end{tabular}


Sodium hypochloride kills microbes by oxidizing biological molecules such as proteins and nucleic acids (Yildiz and Er, 2002). However, mercuric chloride gave better result when compared to sodium hypochloride as its bleaching action of two chloride atoms cause the death of organisms when its ions that combines strongly with proteins. Sodium hypochloride did not five acceptable sterilization percentage even on increasing time and concentration in medicinal plants like Podophyllum hexandrum, Asparagus densiflorous, Balanites aegyptiaca (L.), Cinnamomum camphora, Plumbago zeylanica and Basilium polystachyon, etc. (Sultan et al., 2006; Dasgupta et al., 2007; Gour et al., 2007; Soulange et al., 2007; Sivanesan, 2007; Amutha et al., 2008).

In conclusion, the most frequently used sterilization procedures for in-vitro propagation are conducted with $70 \%$ ethanol, $0.1 \%$ mercuric chloride and $1 \%$ sodium hypochloride. Our results showed that during the sterilization procedure, $0.1 \%$ mercuric chloride at various exposure of time gave good results than $1 \%$ sterilization with sodium hypochloride. Best result was obtained when explants treated with $0.1 \%$ mercuric chloride for 10 minutes. This can be explained by the fct that requirements for surface sterilization are different and depend on the tissue type and the nature of the explants used for in-vitro propagation.

\section{References}

Aberoumand, A., and Deokule, S.S. 2010. Screening of some nutrient and antinutrient components in some plant food of Iran and India. Int. J. Agric Technology. 6(4): 771-781.

Bajaj, Y. P. S. 1986. Biotechnology of tree improvement for rapid propagation and biomass energy production. In:
Biotechnology in agriculture and forestry trees, Springer-Verlag, Heidelberg, Berlin.1: 1-23.

Rattanpal, H. S., G. Kaur and Gupta, M. 2011. In-vitro plant regeneration in rough lemon (Citrus jambhiri Lush) by direct organogenesis. African Journal of Biotechnology. 10(63): 13724-13728.

Badoni, A., and Chauhan, J. S. 2010. In-vitro sterilization protocol for micropropagation of Solanum tuberosum cv. 'KufriHimalini'. Academia Arena. 2(4): 24-27.

Yildiz, M., and Er, C. 2002. The effect of sodium hypochlorite solutions on in vitro seedling growth and shoot regeneration of flax (Linum usitatissimum). Naturwissenschaften. 89(6): 259-261.

Gour, V.S., S.K. Sharma, C.J.S.K. Emmanuel and Kant, T. 2007. A Rapid in-vitro morphogenesis and acclimatization protocol for Balanites aegyptiaca (L) Del- a medicinally important xerophytic tree. J. Plant Biochemistry and Biotechnology.16(2): 151-153.

Dasgupta, C.N., M.J.Mukhopadhyay and Mukhopadhyay, S. 2007. Somatic embryogenesis in Asparagus densiflorus (Kunth) Jessop cv. Sprengeri. J. Plant Biochemistry and Biotechnology.16(2):145-149.

Amutha, R., M.Jawahar and Paul, S.R. 2008. Plant regeneration and in-vitro flowering from shoot tip of Basilicum polystachyon (L.) Moench -An important medicinal plant. $J$. Agriculture Technology. 4(2): 117123.

Soulange, J.G., Ranghoo-Sanmukhiya, V.M. and Seeburrum, S.D. 2007. Tissue culture and RAPD analysis of Cinnamomum camphora \& Cinnamomum verum. Biotechnology, 6(2): 239-244. 
Sultan, P., A.S. Shawl, P.W. Ramteke, A. Jan, 179-184. N.Chisti, N.Jabeen and Shabir, S. 2006. In-vitro propagation for mass multiplication of Podophyllum hexandrum: A high value medicinal herb. Asian J. of Plant Sciences. 5(2):

Sivanesan, I. 2007. Shoot regeneration and somaclonal variation leaf callus cultures of Plumbago zeylanicaLinn. Asian Journal of Plant Sciences. 6(1):83-86.

\section{How to cite this article:}

Minakshi Padhi and Singh, S.P. 2017. Surface Sterilization for Reducing Microbial Contamination in In Vitro Propagation of Lasora (Cordia myxa Roxb.) Using Nodal Segments. Int.J.Curr.Microbiol.App.Sci. 6(8): 836-842. doi: https://doi.org/10.20546/ijcmas.2017.608.106 